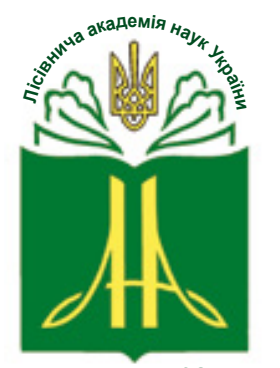

Forestry Academy of Sciences of Ukraine

Наукові праці Лісівничої академії наук України Proceedings of the Forestry Academy of Sciences of Ukraine

http://fasu.nltu.edu.ua

https://doi.org/10.15421/411931

Article received 2019.05.11

Article accepted 2019.12.26
ISSN 1991-606X print

ISSN 2616-5015 online

(a) $\triangle$ Correspondence author

Rimma Matveeva

matveevaRN@yandex.ru

peace Avenue, 82, Krasnoyarsk, 660049, Russia

УДК $630 * 232.31$

\title{
Изменчивость показателей семян сосны кедровой сибирской, произрастающей в разных лесорастительных районах Сибири
}

\author{
Р.Н. Матвеева', О.Ф. Буторова², С. Н. Дырдин ${ }^{3}$, И.Г. Тарасенко ${ }^{4}$
}

\begin{abstract}
Приведены показатели семян сосны кедровой сибирской (Pinus sibirica Du Tour), произрастающей в разных лесорастительных районах Красноярского края и Иркутской области. Объектом исследований явились семена, заготовленные в насаждениях на территории 20 лесничеств. Шишки были собраны в насаждениях и на постоянных лесосеменных участках (ПЛСУ) в конце августа - начале сентября 2016 и 2018 годов. Семена хранились в складских помещениях в ящиках, мешках или россыпью. Исследования проводились с целью изучения массы, жизнеспособности, зрелости семян. Сопоставлены биометрические показатели семян и их посевные качества. Массу 1000 шт., жизнеспособность, класс качества семян определяли на лесосеменной станции Красноярского края. Биометрические показатели и зрелость семян определяли в СибГУ: зрелость устанавливали по заполнению зародышем семенного канала, выраженную в процентах. Размеры, масса семян, их жизнеспособность и зрелость отличались в зависимости от места сбора. Длина семян варьировала от 10,4 до 12,2 мм, ширина - от 7,8 до 9,8 мм, масса 1000 шт. - от 224,8 до 362,2 г, жизнеспособность составила 78-94\%, степень зрелости - 73,1-95,0\%. В 2018 г. масса 1000 шт. семян была больше на 17,9\%. Уровень изменчивости показателей семян в основном низкий и средний. Выделены насаждения, в которых семена имели наибольшие показатели: Назаровское, Козульское (Средне-Сибирский подтаежно-лесостепной район лесостепной зоны), Саяно-Шушенское, Верхне-Манское (Алтае-Саянский горно-таежный район Южно-сибирской горной зоны) лесничества. Установлена значительная и умеренная зависимость между размерами семян и их массой.

Ключевые слова: Pinus sibirica; семена; урожай; жизнеспособность; зрелость; корреляция; лесничество; популяиия; географическое происхождение; Красноярский край; Иркутская область.
\end{abstract}

Введение. Эффективность работ по воспроизводству лесных ресурсов непрерывно связана с качеством используемого посадочного материала. Особая роль отводится изучению полиморфизма древесных растений в высокопродуктивных популяциях. Экологический оптимум сосны кедровой сибирской приурочен к низкогорным районам Алтая, Западного Саяна, где наблюдается высокая

\footnotetext{
Матвеева Римма Никитична - доктор сельскохозяйственных наук, профессор кафедры селекции и озеленения. Сибирский Государственный университет науки и технологий имени академика М.Ф. Решетнева, пр. Мира, 82, г. Красноярск, 660049, Россия. Тел.: (391)227-58-09. E-mail: matveevaRN@yandex.ru ORCID: https://orcid.org/0000-0002-3476-9622

2 Буторова Ольга Федоровна - доктор сельскохозяйственных наук, профессор кафедры селекции и озеленения. Сибирский государственный университет науки и технологий имени академика М.Ф. Решетнева, пр. Мира, 82, г. Красноярск, 660049, Россия. Тел.: (391)227-58-09. E-mail: Butorova.olga@mail.ru ORCID: https://orcid.org/0000-0001-8575-7464

3 Дырдин Сергей Николаевич - кандидат технических наук, доцент кафедры автомобилей и транспортных технологических машин, Сибирский государственный университет науки и технологий имени академика М. Ф. Решетнева, пр. Мира, 82, г. Красноярск, 660049, Россия. Тел.: (391)2275809. E-mail: Sergdirdin@gmail.com ORCID: https://orcid.org/0000-0001-6352-2381

4 Тарасенко Ирина Генриевна - инженер I категории лесосеменной станции «Центр защиты леса Красноярского края» филиала ФБУ «Рослесозащита», ул. Академгородок, 50а, г. Красноярск, 660036, Россия. Тел.: (391)2907523. E-mail: tarasenkoig@rcfh.ru ORCID: https://orcid.org/0000-0002-9976-4576
} 
относительная влажность воздуха при годовом количестве осадков не менее 600 мм, сумме температур выше $10^{\circ} \mathrm{C}$ в пределах $1600-1800^{\circ} \mathrm{C}$ (Krylov et al., 1983 и др.). Климатические экотипы существенно различаются по быстроте роста, фенологии, характеру семеношения и другим показателям (Patlaj, 1976, Hagner, 1980, Matveyev \& Semerikov, 1995, Xu Li-an et al., 1999, Kroon et al., 2008). Исследования особенностей роста и семеношения хвойных видов с учетом географического происхождения проводятся в больших масштабах как в России, так и за рубежом (Nakvasina, 2001, Gabrilavicius, 2002, Xu Liang et al., 2004, Blada, Popescu, 2017, Kuzmina \& Kuzmin, 2017).

Изменчивость показателей семян древесных растений, произрастающих в разных условиях, отражена в литературных источниках (Iroshnikov, 1967, Spodarev, 1967, Zemljanoi, 1974, Vorobiev et al., 1979, Avrov, 1989, Debrinjuk \& Veremchuk, 2014, Matveeva et al., 2017). Размеры, масса семян являются основными показателями, с которыми связаны наследственные свойства и посевные качества. Масса семян считается стабильным популяционным признаком. Установлено, что, несмотря на колебания массы семян у отдельных деревьев в различные годы, их относительный ранг в популяции сохраняется из года в год (Tcherepnin, 1980). Рассматриваются возможности селекции кедра сибирского по таким показателям, как размеры, семенная продуктивность шишек, полнозернистость семян и др. (Putenihina et al., 2014).

T. Hanson (2018) отмечает, что всхожесть семян зависит от развития зародыша, т.е. их зрелости. Влияние качества семян сосны кедровой сибирской на их всхожесть и рост сеянцев рассмотрено в статье Bryncev (1996). Известно, что семена сосны кедровой сибирской дают всходы при осеннем посеве или весеннем после их стратификации. Но если зародыш не полностью заполнил семенной канал, то всходы могут появиться только через год. Поэтому кроме показателей семян, характеризующих крупность и жизнеспособность, большое значение имеет степень развития зародыша, т.е. их зрелость.

Особенно актуально изучение показателей семян сосны кедровой сибирской, поскольку необхо-

димо сохранять ценный генофонд в связи с сокращением кедровых насаждений вследствие пожаров.

Объекты и методы исследований. Объектом исследований явились семена сосны кедровой сибирской, заготовленные в насаждениях, произрастающих на территории 20 лесничеств, расположенных в разных лесорастительных зонах Красноярского края и Иркутской области. Предмет исследований - популяции сосны кедровой сибирской, произрастающие в Алтае-Саянском горно-таежном и Среднесибирском подтаежном лесорастительном районах. Цель работь - изучение массы, жизнеспособности, зрелости семян сосны кедровой сибирской в 2016 и 2018 годах.

Место сбора шишек, таксационная характеристика насаждений (состав, класс бонитета), способ хранения семян устанавливали по паспортам, составленным на каждую партию семян. Массу 1000 шт., жизнеспособность, класс качества семян определяли на лесосеменной станции в Центре защиты леса Красноярского края.

Биометрические показатели и зрелость семян определяли в СибГУ: жизнеспособность - по ГОСТ 13056.7-93, массу - по ГОСТ 13056.4-67. Зрелость семян устанавливали по заполнению зародышем семенного канала, выраженную в процентах.

Сравнительный анализ показателей семян проводили на основе территориально-производственного деления (On approval of the List, 2019). Уровень изменчивости показателей устанавливали по шкале Mamaev (1973).

Статистическую обработку данных, корреляционный, регрессионный анализы проводили, используя пакет программ Microsoft Office.

Результаты и их обсуждение. Анализ материалов по изменчивости размеров, массы, жизнеспособности, зрелости семян позволил выявить некоторые закономерности. Исследования, проведенные в 2016 г. (Matveeva et al., 2017), показали, что масса 1000 шт. семян, их жизнеспособность и зрелость отличались в зависимости от места их сбора. В 2018 г. масса 1000 шт. семян была больше на $17,9 \%$, жизнеспособность - на 6,5\%, зрелость - ниже на 8,0\% в сравнении с 2016 годом (табл. 1).

Таблицุа 1

Показатели семян урожая 2016 и 2018 гг.

\begin{tabular}{lccccccc}
\hline \multicolumn{1}{c}{ Показатель } & $\max$ & $\min$ & $\mathrm{Xcp.}$ & $\pm \mathrm{m}$ & $\mathrm{V}, \%$ & $\mathrm{P}, \%$ & Уровень изменчивости \\
\hline Масса 1000 шт., г & \multicolumn{7}{c}{2016 г. } \\
Жизнеспособность, \% & 317,4 & 211,8 & 253,4 & 5,33 & 10,7 & 2,2 & низкий \\
Зрелость, \% & 95 & 70 & 83,5 & 1,31 & 6,4 & 7,7 & низкий \\
\hline & 99,0 & 76,0 & 94,7 & 1,20 & 6,2 & 1,3 & низкий \\
\hline Масса 1000 шт., Г & 362,2 & 224,8 & 298,8 & 7,10 & 12,3 & 2,4 \\
Жизнеспособность, \% & 94 & 78 & 88,9 & 1,14 & 4,8 & 1,3 & средний \\
Зрелость, \% & 95,0 & 73,1 & 87,7 & 1,90 & 6,7 & 2,2 & низкий \\
\hline
\end{tabular}


Уровень изменчивости показателей семян в 2018 г. в основном низкий $(4,8-6,7 \%)$ и по массе (12,3\%) средний. По данным Putenihina (2015), в 50-летних культурах сосны кедровой сибирской, произрастающих в Башкирском Предуралье, длина семян в среднем составила 10,7 мм, ширина 7,6 мм, масса 1000 штук - 207,0 г.

Максимальные показатели семян в 2016 г. были зафиксированы при сборе шишек в насаждении, произрастающем на территории Верхнеманского, и на ПЛСУ Саяно-Шушенского (Алтае-Саянский горно-таежный лесосеменной район), а также Усинского (Средне-сибирский подтаежный лесосеменной район) лесничеств. Определено наличие связи между размерами и массой семян (табл. 2).

Наличие связи между размерами, массой семян и жизнеспособностью, зрелостью не установлено $(\mathrm{r}=0,012-0,201)$.

В насаждениях лесничеств, относящихся к Среднесибирскому подтаежно-лесостепному райо- ну, средняя длина семян варьирует от 10,4 (Усинское) до 11,8 мм (Б.-Муртинское, Емельяновское, Назаровское, Усольское), то есть различия между вариантами достигают $13,5 \%$, по ширине семян до 20,5\% (табл. 3 ).

По массе выделяются семена из насаждений Назаровского и Усольского лесничеств, которые превосходят среднее значение на 6,2-21,6\%.

Таблииа 2

\section{Коэффициенты корреляции и теснота связи} показателей семян

\begin{tabular}{lcc}
\hline \multicolumn{1}{c}{ Показатель } & $\mathrm{r}$ & Теснота связи \\
\hline $\begin{array}{l}\text { Длина }(\mathrm{L}) \text { и ширина }(\mathrm{d}) \\
\text { семян }\end{array}$ & 0,549 & значительная \\
Длина и масса семян & 0,303 & умеренная \\
Масса и $\mathrm{L} \times \mathrm{d}$ & 0,462 & умеренная \\
Масса и $\mathrm{L} \times \mathrm{d}^{2}$ & 0,487 & умеренная \\
\hline
\end{tabular}

Таблииа 3

\section{Показатели семян сосны кедровой сибирской, заготовленных в насаждениях Среднесибирского подтаежно-лесостепного района лесостепной зоны}

\begin{tabular}{lcccccccccc}
\hline \multirow{2}{*}{ Лесничество } & \multicolumn{2}{c}{ Длина } & \multicolumn{2}{c}{ Ширина } & \multicolumn{2}{c}{ Масса 1000 шт. } & Жизнеспособность & \multicolumn{2}{c}{ Зрелость } \\
\cline { 2 - 10 } & мм & \% к Хср. & мм & \% к Хср. & г & $\%$ к Хср. & $\%$ & $\%$ к Хср. & $\%$ & \% к Хср. \\
\hline Ачинское & 10,5 & 92,9 & 8,0 & 90,9 & 269,5 & 90,5 & 94 & 104,3 & 82,6 & 96,6 \\
Б.-Муртинское & 11,8 & 104,4 & 9,0 & 102,3 & 300,2 & 100,8 & 93 & 103,2 & 81,6 & 95,4 \\
Емельяновское & 11,8 & 104,4 & 8,9 & 101,1 & 277,9 & 93,3 & 81 & 89,9 & 94,8 & 110,9 \\
Козульское & 11,0 & 97,3 & 7,8 & 88,6 & 304,8 & 102,4 & 94 & 104,3 & 95,0 & 111,1 \\
Назаровское & 11,8 & 104,4 & 9,4 & 106,8 & 362,2 & 121,6 & 92 & 102,1 & 84,3 & 98,6 \\
Тулунское & 11,7 & 103,5 & 9,1 & 103,4 & 268,1 & 90,0 & 92 & 102,1 & 86,4 & 101,1 \\
Усинское & 10,4 & 92,0 & 8,6 & 97,7 & 283,8 & 95,3 & 88 & 97,7 & 73,1 & 85,5 \\
Усольское & 11,8 & 104,4 & 9,4 & 106,8 & 316,2 & 106,2 & 87 & 96,6 & 86,3 & 100,9 \\
Среднее значение & 11,3 & 100,0 & 8,8 & 100,0 & 297,8 & 100,0 & 90,1 & 100,0 & 85,5 & 100,0 \\
\hline
\end{tabular}

Жизнеспособность семян колеблется в значительных пределах (81-94\%), при этом самой низкой жизнеспособностью отличаются семена из Емельяновского лесничества. Однако по степени зрелости семена из этого и Козульского лесничеств превосходят семена других вариантов на 12,7-29,7\%, кроме семян из Тулунского и Усольского лесничеств.

В Алтае-Саянском горно-таежном лесорастительном районе длина, ширина, абсолютная масса семян сосны кедровой сибирской варьируют в тех же пределах, что и в Среднесибирском подтаежнолесостепном районе (табл. 4). Наибольшая длина была у семян, заготовленных в насаждениях
Идринского, ширина - Идринского, Даурского, масса - Саяно-Шушенского лесничеств: на $12,6-53,6 \%$ больше, чем в других насаждениях. Мелкие семена сформировались в насаждениях В.-Манского, Ирбейского, Саянского лесничеств.

Жизнеспособность семян в насаждениях данного региона ниже, чем в Среднесибирском подтаежно-лесостепном районе, особенно в насаждениях Манского, Ермаковского лесничеств. Высокой жизнеспособностью (92,5-94\%) отличались семена В.-Манской, Курагинской популяций. Зрелость семян колеблется в пределах 79,4 (С.-Шушенское) - 95,0\% (Манское лесничество). 
Показатели семян по Западносибирскому южно-таежному равнинному району приведены по Пировскому и Тюхтетскому лесничествам (табл. 5).

Длина, ширина, масса, жизнеспособность и зрелость семян в сравниваемых вариантах отличаются незначительно (на 0,8-3,4\%).
В 2016 г. наибольшие размеры и масса 1000 шт. семян отмечены в вариантах, где шишки были собраны в насаждениях Назаровского, жизнеспособность и зрелость семян - Козульского лесничеств. Проведен сравнительный анализ средних значений показателей семян в зависимости от лесорастительной зоны (табл. 6).

Таблиц̧а 4

\section{Показатели семян в насаждениях, произрастающих в Алтае-Саянском горно-таежном} районе южно-сибирской горной зоны

\begin{tabular}{|c|c|c|c|c|c|c|c|c|c|c|}
\hline \multirow{2}{*}{ Лесничество } & \multicolumn{2}{|c|}{ Длина } & \multicolumn{2}{|c|}{ Ширина } & \multicolumn{2}{|c|}{ Macca 1000 шт. } & \multicolumn{2}{|c|}{ Жизнеспособность } & \multicolumn{2}{|c|}{ Зрелость } \\
\hline & мM & $\%$ к Хср. & мM & $\%$ к Хср. & $\Gamma$ & \% к Хср. & $\%$ & \% к Хср. & $\%$ & $\%$ к Хср. \\
\hline В.-Манское & 11,2 & 100,0 & 8,2 & 92,1 & 224,8 & 75,3 & 94,0 & 106,1 & 93,3 & 103,9 \\
\hline Даурское & 11,2 & 100,0 & 9,8 & 110,1 & 310,8 & 104,2 & 88,5 & 99,9 & 93,8 & 104,4 \\
\hline Ермаковское & 10,6 & 90,6 & 9,0 & 101,1 & 305,6 & 102,4 & 85,0 & 95,9 & 92,1 & 102,6 \\
\hline Идринское & 12,0 & 107,1 & 9,4 & 105,6 & 315,2 & 105,6 & 89,0 & 100,4 & 88,8 & 98,9 \\
\hline Ирбейское & 10,8 & 96,4 & 8,7 & 97,8 & 274,6 & 92,0 & 91,7 & 103,5 & 86,5 & 96,3 \\
\hline Кизирское & 11,4 & 101,8 & 8,9 & 100,0 & 303,6 & 101,7 & 91,0 & 102,7 & 93,4 & 104,0 \\
\hline Курагинское & 11,4 & 101,8 & 9,1 & 102,2 & 312,3 & 104,6 & 92,5 & 104,4 & 84,6 & 94,2 \\
\hline Манское & 10,6 & 90,6 & 8,4 & 94,4 & 300,4 & 100,7 & 78,0 & 88,0 & 95,0 & 105,8 \\
\hline Саянское & 11,3 & 100,9 & 9,1 & 102,2 & 291,3 & 97,6 & 87,5 & 98,8 & 90,8 & 101,4 \\
\hline $\begin{array}{l}\text { Саяно- } \\
\text { Шушенское }\end{array}$ & 11,4 & 101,8 & 8,8 & 98,9 & 345,2 & 115,7 & 89,0 & 100,4 & 79,4 & 88,4 \\
\hline Среднее значение & 11,2 & 100,0 & 8,9 & 100,0 & 298,4 & 100,0 & 88,6 & 100,0 & 89,8 & 100,0 \\
\hline
\end{tabular}

Таблииа 5

Показатели семян из насаждений Западносибирского южно-таежного равнинного района таежной лесорастительной зоны

\begin{tabular}{lccccccccccc}
\hline \multirow{2}{*}{ Лесничество } & \multicolumn{2}{c}{ Длина } & \multicolumn{2}{c}{ Ширина } & \multicolumn{2}{c}{ Масса 1000 шт. } & Жизнеспособность & \multicolumn{2}{c}{ Зрелость } \\
\cline { 2 - 11 } & мм & \% к Хср. & мм & \% к Хср. & г & \% к Хср. & $\%$ & \% к Хср. & $\%$ & \% к Хср. \\
\hline Пировское & 11,4 & 96,6 & 9,5 & 102,2 & 308,3 & 101,0 & 86,5 & 100,8 & 83,4 & 97,0 \\
Тюхтетское & 12,2 & 103,4 & 9,0 & 96,8 & 302,2 & 99,0 & 85,0 & 99,1 & 88,5 & 102,9 \\
Среднее значение & 11,8 & 100,0 & 9,3 & 100,0 & 305,2 & 100,0 & 85,8 & 100,0 & 86,0 & 100,0 \\
\hline
\end{tabular}

Показатели семян сосны кедровой сибирской, произрастающей в разных лесорастительных зонах, колеблются в небольших пределах. Различие по длине семян не превышает $5,4 \%$, ширине $6,9 \%$, массе $-3,7 \%$, жизнеспособности $-5,7 \%$, зрелости $-4,4 \%$. Наибольшие различия проявлялись в насаждениях, расположенных в лесничествах внутри лесорастительных зон. Отношение ширины семени к его длине колеблется от 0,71 до 0,88. По данным Nekrasova (1972), это отношение варьирует от 0,70 до 0,72 .

В пределах каждого лесорастительного района выделены лесничества, где семена имели наибольшие показатели. Таксационные показатели насаждений значительно отличаются по составу и классу бонитета (табл. 7). 


\section{Средние показатели семян сосны кедровой сибирской из насаждений разных лесорастительных зон}

\begin{tabular}{|c|c|c|c|c|c|c|c|c|c|c|c|}
\hline \multirow{2}{*}{$\begin{array}{c}\text { Лесорастительная } \\
\text { зона }\end{array}$} & \multirow{2}{*}{$\begin{array}{l}\text { Лесной } \\
\text { район }\end{array}$} & \multicolumn{2}{|c|}{ Длина } & \multicolumn{2}{|c|}{ Ширина } & \multicolumn{2}{|c|}{$\begin{array}{l}\text { Масcа } \\
1000 \text { шт. }\end{array}$} & \multicolumn{2}{|c|}{$\begin{array}{c}\text { Жизне- } \\
\text { способность }\end{array}$} & \multicolumn{2}{|c|}{ Зрелость } \\
\hline & & MM & $\begin{array}{l}\% \text { к } \\
\text { Xсp. }\end{array}$ & MM & $\begin{array}{l}\% \text { к } \\
\text { Xсp. }\end{array}$ & $\Gamma$ & $\begin{array}{l}\% \text { к } \\
\text { Xсp. }\end{array}$ & $\%$ & $\begin{array}{l}\% \text { к } \\
\text { Xcp. }\end{array}$ & $\%$ & $\begin{array}{l}\% \text { к } \\
\text { Хср. }\end{array}$ \\
\hline Лесостепная & $\begin{array}{c}\text { Средне- } \\
\text { сибирский } \\
\text { подтаежно- } \\
\text { лесостепной }\end{array}$ & 11,3 & 100,0 & 8,7 & 97,8 & 295,2 & 98,8 & 90,6 & 101,9 & 85,4 & 97,4 \\
\hline $\begin{array}{l}\text { Южно-сибирская } \\
\text { горная }\end{array}$ & $\begin{array}{c}\text { Алтае-Саянский } \\
\text { горно-таежный }\end{array}$ & 11,2 & 99,1 & 8,9 & 100,0 & 298,4 & 99,9 & 88,5 & 99,6 & 89,8 & 102,4 \\
\hline Таежная & $\begin{array}{c}\text { Западно- } \\
\text { Сибирский } \\
\text { южно-таежный } \\
\text { равнинный }\end{array}$ & 11,8 & 104,4 & 9,3 & 104,6 & 305,2 & 102,1 & 85,5 & 96,2 & 86,0 & 98,1 \\
\hline Среднее значение r & lo опьыту & 11,3 & 100,0 & 8,9 & 100,0 & 298,8 & 100,0 & 88,9 & 100,0 & 87,7 & 100,0 \\
\hline
\end{tabular}

Таблица 7

Таксационные показатели насаждений, где семена имели наиболышие значения

\begin{tabular}{|c|c|c|c|c|}
\hline Лесорастительная зона & Лесной район & Лесничество & Состав древостоя & Класс бонитета \\
\hline \multirow{4}{*}{ Лесостепная } & \multirow{4}{*}{$\begin{array}{c}\text { Среднесибирский } \\
\text { подтаежно-лесостепной }\end{array}$} & \multicolumn{3}{|c|}{ По массе семян } \\
\hline & & Назаровское & 3К5П2Е & II \\
\hline & & \multicolumn{3}{|c|}{ По зрелости семян } \\
\hline & & Козульское & 4К2Е2П2Б & III \\
\hline \multirow{4}{*}{ Южно-сибирская горная } & \multirow{4}{*}{$\begin{array}{l}\text { Алтае-Саянский } \\
\text { горно-таежный }\end{array}$} & \multicolumn{3}{|c|}{ По массе семян } \\
\hline & & С.-Шушенское & 10К (ПЛСУ) & I \\
\hline & & \multicolumn{3}{|c|}{ По жизнеспособности семян } \\
\hline & & В.-Манское & $6 К 4 Б$ & III \\
\hline
\end{tabular}

Крупные семена (урожай 2018 г.) сформировались в насаждениях, произрастающих в Назаровском лесничестве и на ПЛСУ Саяно-Шушенского лесничества. Наибольшая зрелость была у семян из насаждения Козульского, жизнеспособность В.-Манского лесничеств. Класс бонитета - I-III, в составе насаждения, кроме сосны кедровой сибирской, произрастают пихта, ель, береза.

Выводы. Показатели семян сосны кедровой сибирской варьируют в зависимости от многих факторов, включая генетические и условия произрастания. Сопоставляя данные урожая 2016 и 2018 гг. установлено, что наибольшая масса семян была при сборе шишек в течение двух лет в насаждении Назаровского и на ПЛСУ Саяно-Шушенского лесничеств. По жизнеспособности и зрелости семена отличались в зависимости от года сбора шишек. Учитывая, что посевные качества семян влияют на всхожесть и дальнейший рост сеянцев, целесообразно при выращивании посадочного материала использовать в первую очередь семена из выделенных насаждений и ПЛСУ на территории определенного лесного района лесорастительной зоны.

\section{References}

Avrov, F.D. (1989). Sowing quality of seed and phenology development trees township pine stands. In The problem of Cedar. Organization of complex economy (pp. 113-121). Tomsk: Center of the USSR Academy of Sciences (in Russian). 
Blada, I. \& Popescu, F. (2017). Swiss stone pine provenance experiment in Romania: II variation in growth and branching traits to age 14. Silvae Genetica, 56 (1-6), 148-158. https://doi.org/10.1515/ sg-2007-0023

Bryncev, V.A. (1996) Influence of seed quality cedar on dirt germination and seedling growth. Forestry, 6 , 39 (in Russian).

Debrinjuk, Y. M., \& Veremchuk, Yu. S. (2014). Seeding quality of seeds in Abies white in stands of the Ukrainian Carpathians In Gardening, seed growing, introduction of woody plants, 23-26. Krasnoyarsk, Russia: SibSTU (in Russian).

Gabrilavicius, R. (2002). Distribution of Lithuanian Scots pine trees according to breeding categories and their seed production in seed stands. Dendrobiology, 47, 89-92. file:///C:/Users/User/ Downloads/47s_89_92.pdf

Hagner, M. (1980). Geographical variation in seed quality of lodge role pine and within stands. Res. Notes. Pep. Forest Genet. Sured Univ., 30, 275-286.

Hanson, T. (2018). Triumph of seeds: seed subdued flora and impacted on human civilization. Moskow: Alpina non fiction (in Russian).

Iroshnikov, A.I. (1967). Cedar Siberian seeds quality in mountain areas. In Geographical aspects of Mountain Forestry and forest management (pp. 153155). Chita: TRANS-Baikal branch (in Russian).

Kroon, J., Wennstrom, U., Prescher F., Lindgren D., \& Mullin T. J. (2008). Estimation of clonal variation in seed cone production over time in a Scots pine (Pinus sylvestris L.) seed orchard. Silvae genetica, 58 (1-2), 53-62. https://doi.org/10.1515/sg-2009-0007

Krylov, G. V., Talancev, N. K., \& Kozakov N.F. (1983). Cedar. Moskow: Forest industry (in Russian).

Kuzmina, N.A., \& Kuzmin, S. R. (2017). Analysis of the dynamics of growth of Scots pine provenances in geographic cultures in central Siberia. Siberian Journal of Forest Science, 2, 31-39 http://xn-80abmehbaibgnewcmzjeef0c.xn--p1 ai/upload/ iblock/1ad/1adfc4cd11ec 05938ddda10a984045a8. pdf (in Russian).

Mamaev, S.A. (1973). Forms of intraspecific variability of woody plants. Moskow: Science (in Russian).

Matveyev, A. V., \& Semerikov, L.F. (1995). Ecology of Siberian larch. Ecology, 1, 8-19 (in Russian).

Matveeva, R.N., Dyrdin, S.N., \& Tarasenko, I.G. (2017). Variability of Pinus Siberian pine seeds indicators in forest areas of Krasnoyarsk region. In Gardening, seed growing, introduction of woody plants, 103-105. Krasnoyarsk, Russia: SibSTU (in Russian).

Nakvasina, E.N. (2001). Selective evaluation of Climatypes of Common pine in the geographical cultures of the Arkhangelsk region. Forestry Journal, 3, 27-34 https://cyberleninka.ru/article/n/selektsionnaya-otsenka-klimatipov-sosny-obyknovennoy-vgeograficheskih-kulturah-arhangelskoy-oblasti (in Russian).
Nekrasova, T.P. (1972). Biological basis of seed production of Siberian cedar. Novosibirsk: Science

On approval of the List of forest growing zones of the Russian Federation and the List of forest regions of the Russian Federation (2019). Order N 367 of 08/18/2014 as amended on 02/19/2019 Moskov: Ministry of Natural Resources and Ecology of the Russian Federation (in Russian).

Patlaj, I.N. (1976). Growth and stability of pine in geographic cultures of the second generation in Trostjanec forestry, Sumy region. Forestry Journal, 5, 34-37 (in Russian).

Putenihina, K.V., Shigapov, Z.H., Mkrtchyan, M.A. \& Putenihin V.P. (2014). Quantitative values of Cones and Seeds in introduced siberian Stone pine. Coniferous of the boreal zone, 32 (5-6), 59-64 https://cyberleninka.ru/article/n/kolichestvennyepokazateli-shishek-i-semyan-kedra-sibirskogo-priintroduktsii (in Russian).

Putenihina, K. V. (2015). Variability of Cedar generative organs when introduced in Bashkir Predural: breeding opportunities. In The conservation of forest genetic resources of Siberia (pp. 146-147). Krasnoyarsk: Siberian Branch of the Russian Academy of Sciences (in Russian).

Spodarev, N. N. (1967). About the influence of external conditions on the seeding quality cedar siberian seeds. In Works on forestry in Western Siberia (pp. 62-106). Novosibirsk (in Russian).

Tcherepnin, V.L. (1980). Variability of Scots pine seeds. Novosibirsk: Science (in Russian).

Xu Li-an, Wang Z., \& Cao H. (1999). Study variability of offspring free pollinate of Pinus massoniana plus trees in Fujian province. Fujian Linxueyuan Xuebao = Journal of Fujian College of Forest, 19 (2). 114-117.

Xu Liang, Bao W., \& He Y. (2004). Morphological characteristics and geographical variability in cones and seeds in four populations Cupressus chenggiana S.Y. Hu. Yingyong yu Huanjing Shengwu Xuebao = Chin. J. Appl. and Environ. Biol., 10 (6), 707-711.

Vorobiev, V.N. et al. (1979). Cedar seeds. Novosibirsk: Science (in Russian).

Zemljanoi, A.I. (1974). About the nature of the genetic diversity of Cedar seeds in relation to altitudinal zonation in Altai. In State and prospects of development of forest genetics, plant breeding, seed production and introductions. Methods of selection of woody plants (pp. 239-242). Riga (in Russian). 


\section{Variability of pine cedar siberian seeds, which grow in different forest areas of Siberia}

\section{R. Matveeva', O. Butorova², S. Dyrdin'3 , I. Tarasenko ${ }^{4}$}

The indicators for seeds of Pne cedar Siberian (Pinus sibirica $\mathrm{Du}$ Tour) growing in different forest areas of the Krasnoyarsk territory and Irkutsk region have been presented. The object of research was the seeds harvested in the 20 populations. Cones were collected in plantations and on permanent forest seed plots (PFSP) in late August - early September of 2016 and 2018. Seeds were stored in the warehouses in boxes, bags or in bulk. Biometric indicators of seeds and their sowing qualities were compared. Research was conducted to study the mass, viability, and maturity of seeds. A mass of 1000 pcs., viability and quality class of seeds were determined at the forest seed station of the Krasnoyarsk territory. Biometric indicators and seed maturity were determined at SibSU: maturity was specified by filling the seed canal with the embryo, expressed in a percentage. The research conducted in 2016 showed that the mass of $1000 \mathrm{pcs}$. of seeds, their viability and maturity differed depending on the place of their collection. The largest sizes and weight for 1000 pcs. of seeds are marked in the variants where the cones were collected in the Nazarovsky plantations, the viability and maturity of the seeds - from the Kozulsky forestry. In 2018, the mass of 1000 pcs. of seeds was $17.9 \%$ more, viability $-6.5 \%$, maturity was lower by $8.0 \%$ compared to 2016 . The level of seed indicators variability is mainly low (4.8-6.7\%) and by mass $(12.3 \%)$ it was average in 2018 . The maximum seed indicators were found when collecting cones in the plantation of the Verkhnemansky territory, and on the PFSP of the Sayano-Shushensky (Altai-Sayan mountain-taiga forest seed region), as well as the Usinsky (Middle Siberian subtaiga forest seed region) forestry. The relationship between size and weight

Rimma Matveeva - Doctor of Agricultural Sciences, Professor of the Department of breeding and planting SibSU, Reshetnev Siberian State University of Science and Technology Krasnoyarsk, Russian Federation. Tel.: (391)227-58-09. E-mail: matveevaRN@, yandex.ru ORCID: https://orcid.org/0000-0002-3476-9622

Olga Butorova - Doctor of Agricultural Sciences, Professor of the Department of breeding and planting SibSU, Reshetnev Siberian State University of Science and Technology Krasnoyarsk, Russian Federation. Tel.: (391)227-58-09. E-mail: selekcia@sibgtu.ru ORCID: https://orcid.org/0000-0001-8575-7464

Sergiy Dyrdin - PhD of Technology, Associate Professor, Department of Automobiles and Transport Technological Machines, Reshetnev Siberian State University of Science and Technology Krasnoyarsk, Russian Federation. Tel.: (391)227-58-09. E-mail: Sergdirdin@gmail.com ORCID: https://orcid.org/0000-00016352-2381

4 Iryna Tarasenko - Engineer of the 1 category of the Forest seed Station «Center for Forest Protection of the Krasnoyarsk region» of the FSBI «Roslesozashita», str. Akademgorodok, 50a, Krasnoyarsk, 660036, Russian Federation. Tel.: (391)290-75-23. E-mail: tarasenkoig@rcfh.ru ORCID: https://orcid.org/00000002-9976-4576 of the seeds $(r=0.303-0.549)$ was determined. The relationship between size, seed weight and viability, maturity has not been established $(\mathrm{r}=0,012-0,201)$. A comparative analysis of the average values of seed indicators depending on the forest zone was carried out. Indicators of seeds of Pinus sibirica Du Tour, growing in different forest zones, fluctuate within small limits. The difference in seed length does not exceed $5.4 \%$, width $6.9 \%$, weight $-3.7 \%$, viability $-5.7 \%$, maturity $4.4 \%$. The greatest differences were manifested in the stands located in the forest areas inside the forest zones. It has been established that indicators for seeds of Pinus sibirica Du Tour vary depending on many factors, including genetic and growing conditions. Comparing the harvest data of 2016 and 2018, it was found that the largest mass of seeds was during the collection of cones for two years in the Nazarovsky plantation and on the PFSP of the Sayano-Shushensky forestry. Viability and maturity of the seeds differed depending on the year of collection of cones. Considering that the sowing qualities of seeds affect the germination and further growth of seedlings, it is advisable to use seeds from selected stands and PFSP in a particular forest area for growing the planting material.

Key words: Pinus sibirica, seeds, harvest, vitality, maturity, correlation, forestry, population, geographical origin, Krasnoyarsk region, Irkutsk region.

\section{Мінливість показників насіння сосни кедрової сибірської в різних лісорослинних районах Сибіру}

\author{
Р.Н. Матвєєва', О.Ф. Буторова², С.Н. Дирдін ${ }^{3}$, \\ І.Г. Тарасенко ${ }^{4}$
}

Наведено біометричні та якісні показники насіння Pinus sibirica Du Tour), що росте у насадженнях різних лісорослинних районів Красноярського

Матвєєва Рімма Нікітічна - доктор сільськогосподарських наук, професор кафедри селекції та озеленення. Сибірський Державний університет науки і технологій імені академіка М.Ф. Решетньова, пр. Миру, 82, м. Красноярськ, 660049, Росія. Тел.: (391)227-58-09. E-mail: matveevaRN@yandex.ru ORCID: https://orcid.org/0000-0002-3476-9622

Буторова Ольга Федорівна - доктор сільськогосподарських наук, професор кафедри селекції та озеленення. Сибірський Державний університет науки і технологій імені академіка М.Ф. Решетньова, пр. Миру, 82, м. Красноярськ, 660049, Росія. Тел.: (391)227-58-09. E-mail: Butorova.olga@mail.ru ORCID: https://orcid.org/0000-0001-8575-7464

Дирдін Сергій Миколайович - кандидат технічних наук, доцент кафедри автомобілів і транспортних технологічних машин, Сибірський Державний університет науки і технологій імені академіка М.Ф. Решетньова, пр. Миру, 82, м. Красноярськ, 660049, Росія. Тел.: (391)2275809. E-mail: Sergdirdin@, gmail.com ORCID: https://orcid.org/0000-0001-6352-2381

4 Тарасенко Ірина Генрієвна - інженер I категорії лісонасінної станції «Центру захисту лісу Красноярського краю» філіалу ФБУ «Рослісозахист», вул. Академгородок, 50а, м. Красноярск, 660036, Росія. Тел.: (391)2907523. E-mail: tarasenkoig@ rcfh.ru ORCID: https://orcid.org/0000-0002-9976-4576 
краю Іркутської області. Об’єктом досліджень було насіння, заготовлене в насадженнях на території 20-ти лісництв. Шишки заготовляли у насадженнях та на постійних лісонасінних ділянках (ПЛНД) наприкінці серпня - початку вересня 2016 і 2018 років. Насіння зберігали у складських приміщеннях в ящиках, мішках або розсипом. Дослідження здійснювали для вивчення маси, життєздатності, зрілості насіння.

Було співставлено біометричні показники насіння та їхні посівні якості. Масу 1000 шт., життєздатність, клас якості насіння визначали на лісонасінній станції Красноярського краю. Біометричні показники і зрілість насіння визначали в лабораторії Сибірського ДТУ: зрілість встановлювали щодо заповнення зародком насіннєвого каналу, виражену у відсотках. Розміри, маса насіння, його життєздатність і зрілість відрізнялися залежно від місця заготівлі. Довжина насіння варіювала від 10,4 до 12,2 мм, ширина - від 7,8 до 9,8 мм, маса 1000 штук - від 224,8 до 362,2 г, життєздатність становила 78-94\%, ступінь зрілості - 73,1-95,0\%. У 2018 р. маса 1000 шт. насіння була більшою на 17,9\%. Рівень мінливості показників насіння переважно низький і середній. У низці лісництв виділено насадження, в яких насіння мали найбільші показники: Назаровське,
Козульське (Середньо-Сибірський підтайговолісостеповий район лісостепової зони), СаяноШушенське, Верхньо-Манське (Алтайо-Саянський гірничо-тайговий район Південно-сибірської гірської зони) лісництва. Встановлено значну і помірну залежність між розмірами насіння та їхньою масою.

Показники насіння сосни кедрової сибірської варіюють залежно від багатьох чинників, враховуючи генетичні та умови зростання. Зіставляючи дані врожаю 2016 і 2018 рр. встановлено, що найбільша маса насіння була під час збирання шишок впродовж двох років у насадженні Назаровського i на ПЛНД Саяно-Шушенського лісництв. За життєздатністю та зрілістю насіння відрізнялося залежно від року заготівлі шишок. 3 огляду на те, що посівні якості впливають на схожість насіння i подальший ріст сіянців, доцільно під час вирощування садивного матеріалу використовувати передусім насіння 3 виділених насаджень і ПЛНД на території певного лісового району конкретної лісорослинної зони.

Ключові слова: Pinus sibirica; насіння; урожай; життєздатність; зрілість; кореляція; лісництво; популяція; географічне походження; Красноярський край; Іркутська область. 